\title{
Hemşirelik Bölümünde Okuyan Öğrencilerin Özgecilik Düzeyinin Kan Bağışı Tutumuna Etkisi
}

\section{The Effect of Altruism Level of Students in the Nursing Department on the Attitudes of Donating Blood}

\author{
Bahar Çiftçii ${ }^{1}$, Gülcan Bahçecioğlu Turan ${ }^{2}$ \\ ${ }^{1}$ Atatürk Ünversitesi Hemşirelik Fakültesi Hemşirelik Esasları Anabilim Dalı, Erzurum, Türkiye \\ ${ }^{2}$ Fırat Ünversites Sağlık Bilimleri Fakültesi İç Hastalıkları Hemşireliği Anabilim Dalı, Elazığ, Türkiye \\ Yazışa Adresi / Correspondence: \\ Gülcan Bahçecioğlu Turan \\ Fırat Ünversites Sağlık Bilimleri Fakültesi İç Hastalıkları Hemşireliği, 23200 Merkez/Elazığ \\ T: +904242374592 E-mail : glcnbah@hotmail.com \\ Geliş Tarihi / Received : 01.05.2021 Kabul Tarihi / Accepte: 26.08.2021
}

Orcid :

Bahar Çiftçi https://orcid.org/0000-0001-6221-3042

Gülcan Bahçecioğlu Turan https://orcid.org/0000-0002-0061-9490

( Sakarya Tip Dergisi / Sakarya Med J 2021, 11(3):608-615) DOI: 10.31832/smj.930765

\footnotetext{
$\ddot{0} z$

Amaç Bu araștırma, hemșirelik bölümünde okuyan öğrencilerin özgecilik düzeyinin kan bağıșı tutumuna etkisini belirlemek amacıyla yapıldı

Gereç ve Araştırmanın evrenini, Türkiyede bir hemşirelik fakültesinde öğrenim gören 1200 hemşirelik öğrencisi oluşturdu. Araştırmanın örneklemi ise; tanımlanan evrenden Yöntemler araștırmaya katılmayı kabul eden, araştırma kriterlerine uyan ve olasıllklı örneklem yönteminden basit tesadüfi örnekleme yöntemi ile seçilen 321 öğrenci oluşturdu. Araştırmanın verileri Şubat-Nisan 2021 tarihleri arasında "Öğrenci Bilgi Formu”, "Özgecilik Ölçeği” ve "Kan Bağışı Tutum Ölçeği” kullanılarak toplandı. Verilerin değerlendirilmesinde frekans ve yüzde hesapları, ortalama, standart sapma ve Pearson korelasyon analizi yapıldı.

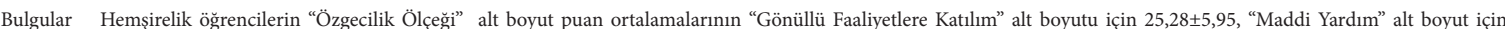

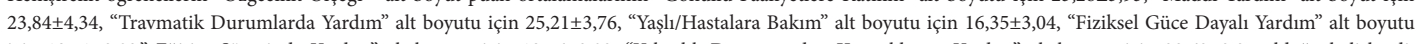

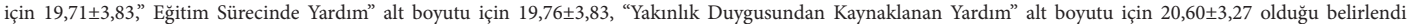

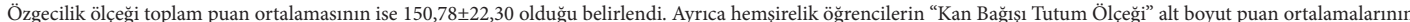

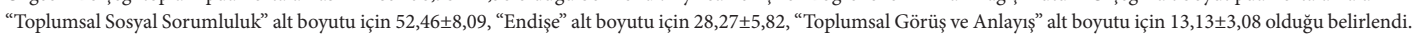
Kan Bağıșı Tutum Ölçeği toplam puan ortalamasının ise $93,86 \pm 12,10$ olduğu belirlendi. Özgecilik düzeyi ile kan bağışı tutumu arasında pozitif yönde bir ilişki olduğu ve bu ilișkinin istatistiksel açıdan orta düzeyde olduğu belirlendi. $\left(r=, 417^{* *}, \mathrm{p}<0,001\right)$

Sonuç Hemşirelik öğrencilerinin özgecilik düzeylerinin yüksek ve kan bağıșına yönelik tutumlarının ise olumlu olduğu saptandı. Ayrıca; hemșirelik öğrencilerinin özgecilik düzeyi artıkça kan bağıșına yönelik tutumlarının olumlu yönde arttığı belirlendi.

Anahtar Hemșirelik öğrencileri; özgecilik; kan bağıșı tutumu

Kelimeler

\begin{tabular}{|c|c|}
\hline Abstract & \\
\hline Objective & This research was carried out to determine the effect of the altruism level of the students studying in the nursing department on the blood donation attitude. \\
\hline $\begin{array}{r}\text { Materials } \\
\text { and Methods }\end{array}$ & $\begin{array}{l}\text { The population of the study consists of } 1200 \text { nursing students studying at the nursing faculty of a state university in Turkey. The sample of the study consists of } 321 \text { students who accepted to } \\
\text { participate in the study in the defined population, who met the research criteria and who were chosen with simple random sampling method, one of the probability sampling methods. The data } \\
\text { in the study were collected between February and April } 2021 \text { by using "Student Information Form", "Altruism Scale" and "Blood Donation Attitude Scale". Frequency and percentage, mean, } \\
\text { standard deviation and Pearson correlation analysis were used to evaluate the data. }\end{array}$ \\
\hline Resulrs & $\begin{array}{l}\text { Mean scores of the students were found as } 25.28 \pm 5.95 \text { for "Participation in voluntary activities" sub-dimension, as } 23.84 \pm 4.34 \text { for "financial support" sub-dimension, as } 25.21 \pm 3.76 \text { for "help } \\
\text { in traumatic situations" sub-dimension, as } 16.35 \pm 3.04 \text { for "care for elderly/patient" sub-dimension, as } 19.71 \pm 3.83 \text { for "help based on physical power" sub-dimension, as } 19.76 \pm 3.83 \text { for "help } \\
\text { in educational process" sub-dimension and as } 20.60 \pm 3.27 \text { for "help due to sincerity" sub-dimension. Altruism scale mean total score was found as } 150.78 \pm 22.30 \text {. In addition, total mean } \\
\text { scores were found as } 52.46 \pm 8.09 \text { for "societal and social responsibility" sub-dimension, as } 28.27 \pm 5.82 \text { for "anxiety" sub-dimension and as } 13.13 \pm 3.08 \text { for "societal perception and conception" } \\
\text { sub-dimension. Total mean score of Blood Donation Attitude Scale was found as } 93.86 \pm 12.10 \text {. It was determined that there was a positive relationship between the level of altruism and the } \\
\text { attitude to donate blood, and this relationship was statistically moderate }\left(r=.417^{* *}, p<0,001\right) \text {. }\end{array}$ \\
\hline Conclusion & $\begin{array}{l}\text { It was found that nursing students had high altruism levels and positive blood donation attitude. It was also found that as nursing students' altruism levels increased, their attitudes towards } \\
\text { blood donation also increased positively. }\end{array}$ \\
\hline Keyword & blood donation attitude; nursing students \\
\hline
\end{tabular}
}




\section{GIIRIŞ}

Kan, insanların yaşamlarını sürdürmeyi temin etmek için çok değerli bir kaynaktır. ${ }^{1}$ Kan bağışı, tam kanın veya bileşenlerinden en az birinin bağışlanması işlemi olarak adlandırılır. İnsan kökenli kanı elde etmenin insandan başka alternatifi bulunmamaktadır. Bu nedenle kan bağışı, bir insanın hayatını kurtarmanın en temel yoludur. ${ }^{3}$

Dünya ülkelerinin büyük çoğunluğunda kan temininin neredeyse tamamı gönüllü bağışlarla sağlanmaktadır. Diğer bir deyişle tek kan kaynağı "gönüllü kan bağışçıları" dır. Ayrıca; Dünya Sağlık Örgütü tarafından kan bağışçıları üç grupta tanımlanmış ve bunlardan en önemlisi gönüllü ve karşılıksız kan bağışçılarıdır. ${ }^{5}$ Kan bağışçıları kime yardım ettikleri bilgisine sahip değillerdir. Bu nedenle kan bağışı davranışının diğer yardım türlerine oranla özgeci bir davranış olma ihtimali daha yüksektir. ${ }^{6}$

Özgecilik hemşirelik değerlerinden biri olup (Alturisim, Diğerkâmlık), bir kişinin başka kişilere kendiliğinden iyilikle gerçekleştirdiği, onlara yarar sağlayan karşılı̆̆ında herhangi bir beklenti olmaksızın yapılan yardım, sorumluluk üstlenme ve bağışta bulunma gibi prososyal davranış şeklinde tanımlanmaktadır. ${ }^{7}$ Motivasyonel bir durum olarak da tanımlanan özgeciliğin nihai hedefi, bir başkasının refahını artırmaktır. Özgecilik takdire şayan bir değerdir ve en iyi insan dürtü ve davranışlarını yansıtır. ${ }^{8}$ Ayrıca; özgecilik, şefkat ve empati gibi diğer yönelimli duygularla karakterize olduğu için mesleğinin henüz başında olan hemşirelik öğrencileri için önemli bir yere sahiptir. ${ }^{9} \mathrm{Hem}$ şirelik öğrencileri üniversite eğitimleri boyunca özgecilik değerini sadece teorik açıdan değil, aynı zamanda ahlaki ve pratik açıdan da anlama ihtiyacı içerisindedirler. Aynı zamanda, profesyonel değerlerden özgeciliğin, hastaların aldığı bakımın kalitesini etkileyebileceğinin farkındadırlar. ${ }^{10}$

"Özgeci davranış", ise herhangi bir karşılık ya da ödül beklentisi olmadan bir başkasına yardım etmeye gönüllü olmaktır. ${ }^{11}$ Hemşireliğin kalbi olarak tasvir edilen özge- ci davranışta, yardımda bulunulan bireyin kim olduğu önemsizdir. ${ }^{7}$ Özgeci bir davranış olduğu düşünülen gönüllü kan bağışlarının gelişmiş ülkelerde nüfusa oranı \% 5’e ulaşırken, ülkemizde bu oran \% 3,6'dır.,12 Dünya üzerinde kan bağışı sayesinde hayatları kurtulan milyonlarca insan bulunurken, diğer taraftan kan bağışı talebi dünya nüfusunun artışı ile doğru orantılı olarak artmaktadır. Günümüzde kan bağışına dair tutum ve davranışların anlaşılması bu nedenle önem kazanmıştır. ${ }^{13}$ Kan bağışına yönelik tutumun ve kan bağışının artırılması için girişimlerde bulunulmalıdır. Kan bağışına yönelik tutumun belirlenmesinde, gönüllüğü sağlamada ve toplumu bilinçlendirmede hemşirelere büyük görevler düşmektedir. Hemşireler, hemşirelik değerlerini içselleştirerek bu görevleri yerine getirmeyi hedeflemelidir. ${ }^{14}$

Bugün ve gelecekte kan bağışlarının büyük çoğunluğunun hemşirelik öğrencileri tarafından karşılanacağı düşünüldüğünde; hemşirelik öğrencilerinin tutumlarını belirlemek kan bağışının arttırılması ve kan bağışına teşvik edici uygulamaların saptanması açısından önemlidir. ${ }^{15}$ Literatürde kan bağışına karşı tutumların değerlendirildiği sınır11 araştırmalar bulunmaktadır. Diğer taraftan hemşireliğin profesyonel değerlerinden biri olan özgeciliğin hemşirelik öğrencilerini ele alan sınırlı sayıda araştırma yapıldığ1 dikkat çekmektedir. Oysaki özgeci davranışların kan bağışına yönelik tutumlarına yönelik araştırmalar, özgeci davranışın kan bağışına yönelik tutumları ile ilgili süreçleri anlamamıza katkı sağlayacaktır. Bu araştırmanın amacı; hemşirelik bölümü öğrencilerinin özgecilik düzeyinin kan bağışı tutumuna etkisinin belirlenmesidir.

\section{Araştırma Soruları}

\section{Hemşirelik öğrencilerinin özgecilik düzeyleri nedir?}

Hemşirelik öğrencilerinin kan bağışına yönelik tutumu nedir?

Hemşirelik öğrencilerinin özgecilik düzeyleri ile kan bağ1şı tutum düzeyleri arasında ilişki var mıdır? 


\section{GEREÇ ve YÖNTEMLER}

\section{Araştırmanın Türü}

Araştırma, tanımlayıcı türde kesitsel bir araştırmadır.

\section{Araștırmanın Yeri, Zamanı ve Özellikleri}

Araştırma Şubat- Nisan 2021 tarihleri arasında Atatürk Üniversitesi Hemşirelik Fakültesi'nde 2020-2021 eğitim öğretim yllında eğitim gören hemşirelik öğrencileri ile gerçekleştirildi.

\section{Araştırmanın Evreni ve Örneklem Seçimi}

Araştırmanın evrenini, Atatürk Üniversitesi Hemşirelik Fakültesi’nde 2020-2021 eğitim öğretim yllında öğrenim gören 1200 hemşirelik öğrencisi oluşturdu. Araştırmanın örneklemi ise; tanımlanan evrende araştırmaya katılmayı kabul eden, araştırma kriterlerine uyan ve olasllıklı örneklem yönteminden basit tesadüfi örnekleme yöntemi ile seçilen 321 öğrenci oluşturdu. Basit tesadüfi örneklemde, araştırma çerçevesindeki öğrencilerin okul numaraları kullanılarak sıralama yapıldı. Okul numarası tek haneli olan öğrencilere veri toplama linki mesaj olarak gönderilirken, okul numarası çift haneli öğrencilere mesaj gönderilmedi. Araştırma yapılmadan önce evreni bilinen örneklem büyüklüğü hesaplaması https://www.calculator. net/sample-size-calculator.html linkinde yapılarak örneklem büyüklüğü, $\% 95$ güven aralığında ve $\% 5$ hata payı ile 292 öğrenci olarak bulundu. Bu sonuçlar doğrultusunda örneklemin yeterli olduğu görüldü.

\section{Araştırmaya dahil edilme kriterleri}

- 18 yaşüstü olma

- 2020-2021 eğitim öğretim yılında öğrenim görme

- Araştırmaya katılmaya gönüllü olma

\section{Verilerin Toplanması}

Araştırmacılar tarafından "Öğrenci Bilgi Formu”, "Özgecilik Ölçeği” ve "Kan Bağışı Tutum Ölçeği” kullanılarak veriler toplandı. Veri toplama formları Google Docs veri sistemine yüklendi. Okul numarası tek haneli olan öğrencilere veri toplama linki gönderildi. Verilere geri dönüş sağlayan 321 hemşirelik öğrencisi araştırmaya dahil edildi. Verilerin toplanma süresi yaklaşı 3-5 dakika sürmekte olup tekrarlanan veri girişlerini engellemek için Google Docs ayarlar kısmından sadece bir kez gönderme butonu tıklanarak veri güvenliği sağlandı.

\section{Veri Toplama Formları Öğrenci Bilgi Formu}

Yaş, cinsiyet, sosyoekonomik düzeyi gibi öğrencilerin demografik özelliklerini sorgulayan soruları içermektedir.

\section{Özgecilik (Altruism) Ölçeği (ÖÖ)}

Ümmet ve ark. (2013) tarafından, bireylerin özgecilik davranışlarını belirlemek için Türk kültürüne uygun olarak geliştirilmiştir. ${ }^{16}$ Ölçekte ters kodlanmış soru bulunmamaktadır. "Gönüllü Faaliyetlere Katılım", "Maddi Yardım", "Travmatik Durumlarda Yardım”, "Yaşl1/Hastalara Yardım”, "Fiziksel Güce dayalı Yardım”, "Eğitim Sürecinde yardım”, "Yakınlık Duygusundan Kaynaklanan Yardım” olmak üzere 7 alt boyuttan oluşmaktadır. 38 maddeden oluşan ölçekten alınabilecek minimum puan 38 iken; maksimum puan 190'dır. Yüksek puan, özgecilik düzeyinin daha yüksek olduğunu göstermektedir. Ölçeğin toplam Cronbach Alpha değeri 0,81 olarak bulunmuştur. ${ }^{16} \mathrm{Bu}$ araştırmada Cronbach Alpha değeri 0,95 olduğu bulundu.

\section{Kan Bağışı Tutum Ölçeği}

Çelik ve Güven (2015) tarafından geliştirilmiş ve geçerlilik güvenirliği yapılmıştır. ${ }^{4}$ Kan bağışına ilişkin tutumları ölçen, 3 alt boyuttan oluşan 24 maddelik 5 'li likert tipi bir ölçektir. Alt boyutlar; "Toplumsal ve Sosyal Sorumluluk", "Endişe" ve "Toplumsal Görüş ve Anlayış" tır. Ölçekten alınabilecek minimum puan 24 iken; maksimum puan 120 'dir. Puanın artması kan bağışına yönelik tutumun olumlu yönde arttığını göstermektedir. Cronbach alpha güvenilirlik katsayısı 0,83’tür.4 Bu araştırmada Cronbach Alpha değeri 0,84 olduğu bulundu.

\section{Verilerin değerlendirilmesi}

Verilerin analizi SPSS 22 paket programı kullanılarak ya- 
pıldı. Verilerin değerlendirilmesinde frekans, yüzde hesapları, ortalama ve standart sapma değerleri kullanıldı. Araştırmanın normal dağılımı Skewness ve Kurtosis değerlerine göre (-2 ile +2 arasında) değerlendirildi. Araştırmanın normal dağılım gösterdiği belirlendi. Katılımcıların özgecilik düzeyleri ve kan bağışına yönelik tutumları aralarındaki ilişkinin incelenmesi için Pearson korelasyon analizi yapıldı. İstatistiksel anlamlılık düzeyi $\mathrm{p}<0,05$ olarak kabul edildi.

\section{Araştırmanın Değişkenleri}

Bağımlı Değişkenler: Araştırmanın bağımlı değişkenleri öğrencilerin özgecilik düzeyleri ve kan bağışına yönelik tutumlarıdır.

Bağımsız Değişkenler: Araştırmanın bağımsız değişkeni, öğrencilerin sosyo-demografik özellikleri oluşturmaktadir.

\section{Araștırmanın Güçlük ve Sınırlılıkları}

Araştırmanın yalnızca bir kurumda yapılmış olması, farklı eğitim programlarından karşılaştırma yapılmamış olması ve belirli tarihler arasında yapılması araştırmanın sınırlıklarını oluşturmaktadır.

\section{Etik ilkeler}

Araştırmaya başlamadan önce Fırat Üniversitesi Girişimsel Olmayan Araştırmalar Etik Kurulu'ndan etik kurul onayı alındı (02.02.2021 tarihli ve 2021/03-28 sayılı). Atatürk Üniversitesi Hemşirelik Fakültesi'nden kurum izni alındı. Araştırma Helsinki İlkeler Deklarasyonuna uygun olarak gerçekleştirildi. Araştırmaya katılan öğrencilerin onamları alınarak, gönüllülük esasına dayalı katılımları sağlandı.

\section{BULGULAR}

Öğrencilerin \%46,4'ünün 20-21 yaş aralığında, \%75,7’sinin kadın, \%29'unun 2. sinif, \%63,2'sinin not ortalamasinın 3-4 aralığında, \%77,6'sının çekirdek aileye sahip olduğu bulundu. Öğrencilerin \%73,8'inin 3 ve üzeri kardeşe sahip olduğu, \%59,5’inin gelirinin giderine denk olduğu, \%90,3’ünün hayatının büyük bir kısmını ilde geçirdiği belirlendi (Tablo 1).

\begin{tabular}{|c|c|c|c|}
\hline & & $\mathrm{n}$ & $\%$ \\
\hline \multirow{3}{*}{ Yaş } & $18-19$ & 69 & 21,5 \\
\hline & $20-21$ & 149 & 46,4 \\
\hline & 22 ve üstü & 103 & 32,1 \\
\hline \multirow{2}{*}{ Cinsiyet } & Kadın & 243 & 75,7 \\
\hline & Erkek & 78 & 24,3 \\
\hline \multirow{4}{*}{ Sinif } & 1 & 90 & 28,0 \\
\hline & 2 & 93 & 29,0 \\
\hline & 3 & 64 & 19,9 \\
\hline & 4 & 74 & 23,1 \\
\hline \multirow{3}{*}{ Not Ortalaması } & $0-1,99$ & 8 & 2,5 \\
\hline & $2-2,99$ & 110 & 34,3 \\
\hline & $3-4$ & 203 & 63,2 \\
\hline \multirow{2}{*}{ Aile yapısı } & Çekirdek & 249 & 77,6 \\
\hline & Geniş & 72 & 22,4 \\
\hline \multirow{4}{*}{ Kardeş sayısı } & 0 & 5 & 1,6 \\
\hline & 1 & 24 & 7,5 \\
\hline & 2 & 55 & 17,1 \\
\hline & 3 ve üzeri & 237 & 73,8 \\
\hline \multirow{3}{*}{ Gelir Düzeyi } & "Gelir Giderden Az" & 86 & 26,8 \\
\hline & "Gelir Gidere Eşit" & 191 & 59,5 \\
\hline & "Gelir Giderden Fazla" & 44 & 13,7 \\
\hline \multirow{3}{*}{ En uzun yaşanılan yer } & Köy & 15 & 4,7 \\
\hline & İlçe & 16 & 5,0 \\
\hline & İl & 290 & 90,3 \\
\hline
\end{tabular}

Öğrencilerin "Gönüllü Faaliyetlere Katılım" alt boyutunun 25,28 $\pm 5,95$, "Maddi Yardım" alt boyutunun 23,84 $\pm 4,34$, “Travmatik Durumlarda Yardım” alt boyutu-

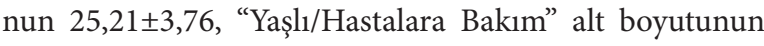
16,35 $\pm 3,04$, "Fiziksel Güce Dayalı Yardım" alt boyutunun $19,71 \pm 3,83$," Eğitim Sürecinde Yardım” alt boyutunun 19,76 $\pm 3,83$, "Yakınlık Duygusundan Kaynaklanan Yardım" alt boyutunun 20,60 $\pm 3,27$ olduğu belirlendi. Özgecilik ölçeği toplam puan ortalamasının ise 150,78 $\pm 22,30$ olduğu belirlendi (Tablo 2). 


\begin{tabular}{|l|l|}
\hline \multicolumn{2}{|l|}{$\begin{array}{l}\text { Tablo 2: Hemşirelik Öğrencilerinin Özgecilik Ölçeği, Kan Bağışı } \\
\text { Tutum Ölçeği ve Alt Boyutları Toplam Puan Ortalamaları }\end{array}$} \\
\hline Özgecilik Ölçeği & \pm SS \\
\hline Gönüllü Faaliyetlere Katılım & $25,28 \pm 5,95$ \\
\hline Maddi Yardım & $23,84 \pm 4,34$ \\
\hline Travmatik Durumlarda Yardım & $25,21 \pm 3,76$ \\
\hline Yaşlı/Hastalara Bakım & $16,35 \pm 3,04$ \\
\hline Fiziksel Güce Dayalı Yardım & $19,71 \pm 3,83$ \\
\hline Eğitim Sürecinde Yardım & $19,76 \pm 3,83$ \\
\hline Yakınlık Duygusundan Kaynaklanan Yardım & $20,60 \pm 3,27$ \\
\hline Toplam Özgecilik & $150,78 \pm 22,30$ \\
\hline Kan Bağışı Tutum Ölçeği & \\
\hline Toplumsal Sosyal Sorumluluk & $52,46 \pm 8,09$ \\
\hline Endișe & $28,27 \pm 5,82$ \\
\hline Toplumsal Görüşve Anlayış & $13,13 \pm 3,08$ \\
\hline Toplam Kan Bağış Tutumu & $93,86 \pm 12,10$ \\
\hline
\end{tabular}

Öğrencilerin “Toplumsal Sosyal Sorumluluk” alt boyu-

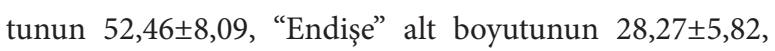
“Toplumsal Görüş ve Anlayış" alt boyutunun 13,13 $\pm 3,08$ olduğu belirlendi. Kan Bağışı Tutum Ölçeği toplam puan ortalamasının ise $93,86 \pm 12,10$ olduğu belirlendi (Tablo 2). Hemşirelik öğrencilerinin özgecilik düzeyi ile kan bağışı tutumu arasında $p<0,001$ düzeyinde pozitif yönde bir ilişki olduğu ve bu ilişkinin istatistiksel açıdan orta düzeyde olduğu belirlendi ( $\left.r=, 417^{* *}, \mathrm{p}<0,001\right)$ (Tablo 3).
Tablo 3: Hemşirelik Öğrencilerinin Özgecilik Ölçeği, Kan

Bağışı Tutum Ölçeği ve Alt Boyutları Toplam Puan Ortalamaları Arasındaki İlişki

\begin{tabular}{|c|c|c|c|c|c|}
\hline & 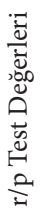 & 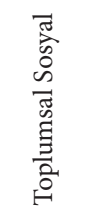 & 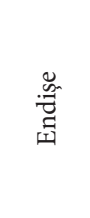 & 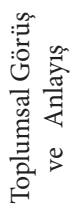 & 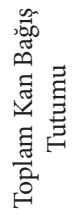 \\
\hline \multirow{2}{*}{$\begin{array}{l}\text { Gönüllü Faaliyetlere } \\
\text { Katılım }\end{array}$} & $\mathrm{r}$ &, $241^{* *}$ &, 020 &,- 044 &, $160^{* *}$ \\
\hline & $\mathrm{p}$ & ,000 &, 721 &, 432 &, 004 \\
\hline \multirow{2}{*}{ Maddi Yardım } & $\mathrm{r}$ &, $412^{* *}$ &, 048 &,- 015 &, $295^{* *}$ \\
\hline & $\mathrm{p}$ &, 000 & ,391 &, 787 &, 000 \\
\hline \multirow{2}{*}{$\begin{array}{l}\text { Travmatik Durum- } \\
\text { larda Yardım }\end{array}$} & $\mathrm{r}$ &, $612^{* *}$ &, $161^{\star *}$ &,- 039 &, $477^{* *}$ \\
\hline & $\mathrm{p}$ &, 000 & ,004 &, 488 &, 000 \\
\hline \multirow{2}{*}{$\begin{array}{l}\text { Yaşlı/Hastalara } \\
\text { Bakım }\end{array}$} & $\mathrm{r}$ &, $477^{* *}$ &, $173^{* *}$ &,- 045 &, $391^{* *}$ \\
\hline & $\mathrm{p}$ &, 000 & ,002 &, 426 &, 000 \\
\hline \multirow{2}{*}{$\begin{array}{l}\text { Fiziksel Güce Dayalı } \\
\text { Yardım }\end{array}$} & $\mathrm{r}$ &, $432^{* *}$ & $207^{* *}$ &, 016 &, $393^{* *}$ \\
\hline & $\mathrm{p}$ & , 000 & ,000 & ,780 &, 000 \\
\hline \multirow{2}{*}{$\begin{array}{l}\text { Eğitim Sürecinde } \\
\text { Yardım }\end{array}$} & $\mathrm{r}$ &, $434^{* *}$ &, $129^{*}$ &,- 009 &, $351^{* *}$ \\
\hline & $\mathrm{p}$ &, 000 & 020 & 876 &, 000 \\
\hline \multirow{2}{*}{$\begin{array}{l}\text { Yakınlık Duygusun- } \\
\text { dan Kaynaklanan } \\
\text { Yardım }\end{array}$} & $\mathrm{r}$ &, $535^{\star *}$ &, $179^{* *}$ &,- 024 &, $438^{* *}$ \\
\hline & $\mathrm{p}$ & ,000 & 001 & ,668 &, 000 \\
\hline \multirow{2}{*}{ Toplam Özgecilik } & $\mathrm{r}$ &, $529^{* *}$ &, $146^{\star *}$ &,- 029 &, $417^{* *}$ \\
\hline & $\mathrm{p}$ &, 000 & ,009 &, 559 &, 000 \\
\hline
\end{tabular}

\section{TARTISSMA}

Araştırma sonucunda elde edilen bulgular ilgili literatür ışığında tartışıldı. Bu araştırmada hemşirelik öğrencilerinin özgecilik düzeylerinin yüksek $(150,78 \pm 22,30)$ olduğu belirlendi. Kaçar Banbal ve Taşocak (2010), Pehlivan ve Lafçı (2014) ve Avcı ve ark.'larının (2013) yaptıkları araştırmalarında; hemşirelik öğrencilerin özgecilik düzeylerinin ortalamanın üzerinde olduğunu bulmuştur. ${ }^{17-19}$ Arpacı ve Özmen'in (2014) ve Timmins ve ark.'nın (2018) yaptıkları araştırmalarda da hemşirelik öğrencilerinin özgecilik düzeyinin yüksek olduğunu belirtilmektedir. ${ }^{20,21}$. Diğer taraftan; Johnson ve ark. (2007) yaptıkları yirmi ylllık bir araştırmada; hemşirelik öğrencilerinin her geçen yıl özgecilik seviyesinin düştüğünü bulmuşlardır. ${ }^{22}$ Cho ve ark. (2010) yaptıkları araştırmada; fedakarlığın zaman içinde zayıfladığını ve bugün eskisi kadar değerli olmadığını gös- 
termektedir. ${ }^{23}$ Litaratürde farklı sonuçlar bulunmuştur. Bu durum kültürel değerlerin farklılıklardan kaynaklanmış olabilir. Bu araştırmada; hemşirelik öğrencilerinin özgecilik düzeylerinin yüksek olmasının nedeni; hemşirelik bakımına muhtaç olan hastalarla sürekli iletişim ve etkileşim halinde olmalarından, verilen etik eğitimden ve özgecilik kavramının hemşirelik değerleri arasında yer almasından kaynaklanmış olabilir.

$\mathrm{Bu}$ araştırmada; öğrencilerin kan bağışına yönelik olumlu tutum sergiledikleri belirlendi $(93,86 \pm 12,10)$. Efteli ve ark. (2018) yaptıkları araştırmada; öğrencilerin kan bağışı tutum ölçeğinin toplam puan ortalaması $83,47 \pm 9,47$ olarak bulunmuş ve hemşirelik bölümü öğrencilerinin kan bağ1şına yönelik tutumlarının olumlu olduğu belirlenmiştir. ${ }^{24}$ Ahmed ve ark. (2017) hemşirelik öğrencileriyle yaptıkları araştırmada öğrencilerin olumlu tutuma sahip olduğu belirlenmiştir. ${ }^{25}$ Melku ve ark. (2018) yaptıkları araştırmada; Sağlık Bilimleri yüksek lisans öğrencilerinin olumlu tutumu olduğunu bulmuşlardır. ${ }^{26}$ Raghuwanshi ve ark. (2016) yaptıkları araştırmaya göre; öğrencilerin kan bağışına karşı olumlu bir tutuma sahip olduğunu göstermektedir. ${ }^{27}$ Arap öğrenciler arasında yapılan mevcut araştırmalar, kan bağışı konusunda olumlu tutumun olduğunu göstermiştir. $^{28-31}$ Literatürde üniversite öğrencilerinin kan bağışına yönelik tutumlarını değerlendiren benzer araştırmalara bakıldığında; üniversitelerin sağlıkla ilgili bölümlerinde yapılan pek çok araştırmada benzer şekilde öğrencilerin kan bağışı konusunda olumlu tutuma sahip oldukları belirlenmiştir. ${ }^{13,32,33}$ Yapılan araştırmalar, sağlık alanında öğrenim gören ya da çalışanların kan bağışına karşı farkındalığının yüksek olduğunu ortaya koymaktadır. ${ }^{2,32,34}$ Hemşirelik öğrencilerin kan bağışına yönelik olumlu tutum sergilemelerinin nedeni, kanın yaşam için önemini bilmelerinden, kan bağışından sonra kurtarılan yaşamları fark etmelerinden, kan transfüzyonu yapılan hastaların olumlu gelişiminden, yaşam mücadelesi veren hastalara birebir bakım vermelerinden ve aldıkları sağlık eğitiminden kaynaklanmış olabilir.
$\mathrm{Bu}$ araştırmada hemşirelik öğrencilerinin özgecilik düzeyi ile kan bağışı tutumu arasında $\mathrm{p}<0,01$ düzeyinde pozitif yönde bir ilişki olduğu ve bu ilişkinin istatistiksel açıdan orta düzeyde olduğu belirlendi. Khani ve ark. (2017) ve Yekefallah ve ark.'nın (2019) yaptıkları araştırmalarda; özgecilik toplam puanı ile organ bağışına yönelik tutumları ile doğrudan ve anlamlı bir ilişki bulunmuştur. ${ }^{35,36}$ Hill ve ark.'nın (2016) yaptıkları araştırmada, özgecilik ile organ bağışına yönelik tutum arasında orta düzeyde pozitif bir korelasyon olduğunu göstermiştir. ${ }^{37}$ Khani ve ark.'nın (2014) yaptıkları araştırmada; organ bağışına yönelik tutum ile özgecilik arasında pozitif ve anlamlı bir ilişki olduğu görülmüştür. ${ }^{38}$ AlHejaili ve ark. (2018) yaptıkları araştırmada organ bağışı genel özgecilik puanı, özgecilik puanından anlamlı derecede yüksek olduğunu bulmuşlardır. ${ }^{39}$ Lim ve Yeom’nın (2020) üniversite öğrencileriyle yaptığı araştırmada; kan bağışı tutumu ve özgecilik arasında ( $r$ $=, 447 \mathrm{p}<, 001)$ anlamlı düzeyde pozitif korelasyon göstermiştir. ${ }^{40}$ Özgecilik düzeyi, bir grup hemşirelik ve sağlık görevlisi öğrencisinde organ bağışı hakkında karar vermeyi etkileyebilir. ${ }^{41}$ Özgecilik duygusunun öğrenci hemşirelerin kan bağışına yönelik tutumlarında önemli bir etkiye sahip olduğu ve öğrenci hemşirelerin kan bağışı için bireylerin rızasını artırma performanslarını artırdığı söylenebilir.

\section{SONUÇ ve ÖNERÍLER}

Hemşirelik öğrencilerinin özgecilik düzeylerinin yüksek ve kan bağışına yönelik tutumlarının olumlu olduğu saptandı. Ayrıca; hemşirelik öğrencilerinin özgecilik düzeyi ile kan bağışı tutumu arasında pozitif yönde orta düzeyde anlamlı bir ilişki olduğu belirlendi.

\section{Bu sonuçlar doğrultusunda,}

Araştırmanın sonuçları, özgeciliğin hemşirelik öğrencilerinin kan bağışına karşı olumlu tutumlarına yol açabileceğini ve kan bağışı sürecindeki performanslarını iyileştirebileceğini ve nihayetinde toplumda kan bağışının statüsünü destekleyebileceğini göstermektedir. Özgeciliğin kan bağışı sürecini nasıl etkilediğini anlamak için daha fazla araştırmaya ihtiyaç vardır. Kan bağışı alanında 
araştırmanın gerekliliği ve toplumun buna artan ihtiyacı göz önünde bulundurularak, hemşirelik öğrencileri arasında kan bağışına yönelik olumlu tutumu güçlendirmek ve özgecilik duygularını artırmak için farklı yöntemlerin kullanılması önerilmektedir.

Hemşirelik öğrencilerinin kan bağışına yönelik tutumları ve özgeci davranışlarının incelenmesi için daha büyük gruplarla çalışılmasına, nicel ve nitel ileri araştırmalar yapılmasına gereksinim vardır.

\section{Etik Kurulu Onayı}

Fırat Üniversitesi Girişimsel Olmayan Araştırmalar Etik kurulu'ndan 02.02.2021 tarihli ve 2021/03-28 say1 nolu etik kurul onayı alındı. 
Sakarya Tip Dergisi 2021;11(3):608-615

ÇíFTÇi ve Ark., Özgecilik Düzeyinin Kan Bağııı Tutumuna Etkisi

\section{Kaynaklar}

1. Garraud O, Tissot J-D. Blood donation and/or donated blood acceptance: the different stakeholders' ethical considerations. Ethics, Medicine and Public Health 2016;2(2):213-219.

2. Özpulat F. Üniversite öğrencilerinin kan ve organ bağıssıına ilişkin düşünceleri. Sağlk Bilimleri ve Meslekleri Dergisi 2017;4(2):71-79.

3. Argan MT. Kan Bağış Davranışııı Etkileyen Faktörlerin Planlı Davranış Teorisi Çerçevesinde İncelenmesi. Acıbadem Üniversitesi Sağllk Bilimleri Dergisi 2016;(2):96-104.

4. Çelik C, Güven G. Kan bağıșı tutum ölçeğinin geliștirilmesi: geçerlilik ve güvenilirlik çalışması. EÜ Eğitim Fakültesi Dergisi 2015;17(2):504-520.

5. Cantürk E, Ceylan S, Akgün UY, Kulular AY,Kurultus Y, Alnawajha A, et al. "Gönüllülük" kan merkezlerine başvuruda fark yaratır mı? Ankara'da seçilmiş kan merkezleri başvuruları üzerinden bir değerlendirme. Türkiye Halk Sağlğ̆ı Dergisi 2013;11(2):86-95.

6. Düzgüner S, Bahadır A. Maneviyat algısı ve diğerkâmlıkla ilişkisi: Kan bağıșı örneğinde Türkiye ve Amerika karșllaștırmalı nitel bir araștırma. Konya,Sosyal Bilimler Enstitüsü,Necmettin Erbakan Üniversitesi; 2013.

7. Milton C. Altruism. Nursing Science Quarterly 2012;25(3):222-224.

8. Giuffra M. Altruism is the heart of our story. Nurs Outlook 2013;61:67-69.

9. Batson CD. A Scientific Search for Altruism: Do We Only Care About Ourselves?: Oxford University Press; 2018.

10. Lyneham J, Levett-Jones T. Insights into Registered Nurses' professional values through the eyes of graduating students. Nurse Education in Practice 2016;17:86-90.

11. Taylor C, Lynn P, Bartlett J. Fundamentals of nursing: The art and science of person-centered care: Lippincott Williams \& Wilkins; 2019.

12. Türk Kızlayı Kan Hizmetleri Genel Müdürlüğü. 2016; http://www.kanver.org/Upload/Dokuman/Dosya/9348 8678_khgm_2016.pdf Accessed 29.04.2021.

13. Küçükkara G, Dönmez TB, Altindiş A, Arslan FG, Altindiş S. Üniversite öğrencilerinin kan bağıșı konusundaki farkındalikları ve yaklaşımları. Journal of Human Rhythm 2017;3(3):151-156.

14. Poorchangizi B, Borhani F, Abbaszadeh A, Mirzaee M, Farokhzadian J. The importance of professional values from nursing students' perspective. BMC nursing 2019;18(1):1-7.

15. Söylemez BA, Ordin YS. Attitudes of the third-year nursing students toward organ donation: Cross-sectional study. In Transplantation proceedings 2017;49(8):1689-1701.

16. Ümmet D, Halil E, Otrar M. Özgecilik (altruism) ölçeği gelişstirme çalışması. Değerler Eğitimi Dergisi 2013;11(26):301-321.

17. Avci D, Aydin D, Özbaşaran F. Hemşirelik Öğrencỉlerİnde Empati-Özgecilik İlişkisi Ve Özgeci Davranişin Bazi Değişkenler Açisindan İncelenmesi. Balıkesir Sağlık Bilimleri Dergisi 2013;2(2):108-113.

18. Kaçar BG, Taşocak G. Hemşirelik Öğrencilerinin Özgecilik Düzeyleri. İstanbul: Sağhlk Bilimleri Enstitüsü, İstanbul Üniversitesi.2010.

19. Pehlivan S, Lafçı D. Altruism levels of nursing students. Gaziantep Medical Journal 2014;20(1):29-34.

20. Arpacı P, Özmen D. Hemşirelik öğrencilerinin özgecilik ve empatik eğilim düzeyleri ve aralarındaki ilişki. Hemşirelikte Eğitim ve Araștırma 2014;11(3):51-57.

21. Timmins F, King C, de Vries JM, Johnson M, Cullen JG, Haigh C. Altruism, honesty and religiosity in nursing students. Journal of clinical nursing 2018;27(19-20):3687-3698.

22. Johnson $M$, Haigh C, Yates-Bolton $N$. Valuing of altruism and honesty in nursing students: a two-decade replication study. Journal of advanced nursing 2007;57(4):366-374.

23. Cho S-H, Jung SY, Jang S. Who enters nursing schools and why do they choose nursing? A comparison with female non-nursing students using longitudinal data. Nurse Education Today. 2010;30(2):180-186.

24. Efteli E, Tuğrul E, Ergin S. Hemșirelik Bölümü Öğrencilerinin Kan Bağıssına Yönelik Tutumlarının Belirlenmesi. Hemșirelik Bilimi Dergisi 2018;1(1):5-9.
25. Ahmed MM, Ali Hussein A, Youns NM. Knowledge, Attitude, and Practice (KAP) of Voluntary Blood Donation among Nurses in Mosul Teaching Hospital. Mosul Journal of Nursing 2017;5(1):24-32.

26. Melku M, Asrie F, Shiferaw E, et al. Knowledge, attitude and practice regarding blood donation among graduating undergraduate health science students at the University of Gondar, Northwest Ethiopia. Ethiopian journal of health sciences 2018;28(5).

27. Raghuwanshi B, Pehlajani NK, Sinha MK. Voluntary blood donation among students-a cross-sectional study on knowledge and practice vs. attitude. Journal of clinical and diagnostic research: JCDR 2016;10(10):EC18.

28. Al-Johar A-W, Al-Saud A, Abalkhail Y, Jawdat T, Khamees S-A, Thunayan Faisal A, et al. Why do-Saudi Women Refrain Donating Their Blood?--a Study on the Attitude, Belief and Motivation of Saudi Female University Students Towards Blood Donation. Clinical laboratory 2016;62(5):771-779.

29. Batiha AM, AlBashtawy M. Knowledge of Philadelphia University students regarding blood donation. Transfusion Medicine 2013;23(3):195-198.

30. Mustafa MM, Abdelfattah EN, Al Rukban M. Attitude towards blood donation among university students. IJSBAR 2015;19:82-91.

31. Baig M, Habib H, Haji AH, Alsharief FT, Noor AM, Makki RG. Knowledge, misconceptions and motivations towards blood donation among university students in KSA. Pakistan journal of medical sciences 2013;29(6):1295.

32. Daștan NB, Daștan M, Kuranşal N. Practices and attitudes towards blood donation in health high school students. Journal of Human Sciences 2013;10(1):293-306.

33. Singh S, Chandrappa M, Venkatesha M, Anil N. Blood donation awareness and beliefs among medical and nursing students. Int J Med Sci Public Health 2015;4(10):1338-1342.

34. Nwogoh B, Aigberadion U, Nwannadi AI. Knowledge, attitude, and practice of voluntary blood donation among healthcare workers at the University of Benin Teaching Hospital, Benin City, Nigeria. Journal of blood transfusion 2013;2013.

35. Khani L, Hashemianfar SA, Ghaffari M, Smaili R. The Role of Moral Beliefs and Altruism in Explaining Attitudes toward Organ Donation with the Mediation of Act to Religious Beliefs. Medical Ethics Journal 2017;11(39):45-53

36. Yekefallah L, Dehghankar L, Taherkhani M, Ranjbaran M. The Role Of Altruism And Empathy In Anticipating The Attitude Toward Organ Donation Among Nurses In Intensive Care Units Of Qazvin: A Cross-Sectional Study. Вестник трансплантологии и искусственных органов 2019;21(4):155-162.

37. Hill EM. Posthumous organ donation attitudes, intentions to donate, and organ donor status: Examining the role of the big five personality dimensions and altruism. Personality and Individual Differences 2016;88:182-186.

38. Khani L, Ghaffari M, Hashemian Far S. The Role of Social Capital and Altruism in Prediction of Medical Doctors' Attitudes to Organ Donation. Journal of Babol University Of Medical Sciences 2014;16(8):19-25.

39. AlHejaili W, Almalik F, Albrahim L, Alkhaldi F, AlHejaili A, Al Sayyari A. Scores of awareness and altruism in organ transplantation among Saudi health colleges students-impact of gender, year of study, and field of specialization. Saudi Journal of Kidney Diseases and Transplantation 2018;29(5):1028.

40. Lim S, Yeom Y-R. The Relationship between Blood Donation Knowledge, Attitude and Altruism of Nursing Students. Journal of Convergence for Information Technology 2020;10(8):68-76.

41. Milaniak I., Wilczek-Ruzyczka E., Przybyłowski P. The role of empathy and altruism in organ donation decision making among nursing and paramedic students Transplant Proc 2018; 50 (7) :1928-1932 